\title{
Article
}

\section{Modernising the Energy Charter Treaty: An Opportunity to Enhance Legal Certainty in Investor-State Dispute Settlement}

\author{
Cees Verburg \\ University of Groningen, The Netherlands \\ c.g.verburg@rug.nl
}

\begin{abstract}
The Energy Charter Treaty is a multilateral trade and investment agreement that is currently the most often-invoked investment agreement worldwide. A review of the case law under the treaty shows that its provisions have been interpreted and applied inconsistently by arbitral tribunals and domestic courts. Considering the financial and reputational consequences of investment arbitration for both the investor and the State, a lack of 'legal certainty' adversely affects all parties involved. This article identifies various inconsistencies, some of the causes, and proposes solutions that could enhance legal certainty in investor-State dispute settlement under the treaty. This is a timely contribution as the Energy Charter Conference has recently taken the first steps
\end{abstract}

* PhD Researcher (Groningen Centre of Energy Law, University of Groningen, the Netherlands). I would like to express my gratitude for the valuable feedback that I received on earlier drafts of this article from Prof Dr Marcel MTA Brus, Prof Dr Panos Merkouris, the discussants at the 6th Conference of the Postgraduate and Early Professionals/Academics Network of the Society of International Economic Law, held in April 2017 at Tilburg University, and the reviewers and editors of JWIT. Any errors remain my own. Also, I want to acknowledge that this research has benefitted from the support of the Dutch Energy Law Association (NeVER) and Stibbe.

(C) CEES VERBURG, 2019 | DOI:10.1163/22119000-12340144

This is an open access article distributed under the terms of the prevailing CC-BY-NC license at the time of publication. 
to modernise the treaty by approving a list of topics for reform, and is now considering tools to implement future reform measures.

\section{Keywords}

Energy Charter Treaty - dispute settlement - legal certainty - rule of law - treaty interpretation

\section{Introduction}

The Energy Charter Treaty (ECT) is a multilateral investment agreement negotiated in the early 1990s. With more than $5^{0}$ Contracting Parties in primarily Europe and Asia, it is arguably the most important international investment agreement (IIA) in existence. The ECT does not only protect investments in the energy sector, where there is an abundance of political risk for longterm investments that are capital intensive and can involve sunk costs, but the ECT is also at present by far the most often invoked IIA in investor-State disputes with 120 known cases. ${ }^{1}$ As the energy sector is strictly regulated in most jurisdictions and States should be able to impose, for example, bona fide environmental regulations without violating international obligations, it is of profound importance for both States and investors that they are able to predict what is protected under the treaty. ${ }^{2}$ For a State, the determination of whether or not such regulations might violate the ECT is for example important in order to avoid regulatory chill. This, however, requires a certain level of predictability in terms of how adjudicators interpret and apply treaty provisions.

The principle of legal certainty, which is essential to the rule of law, entails the 'idea that the law must be sufficiently clear to provide those subject to legal norms with the means to regulate their own conduct and to protect against the arbitrary exercise of public power.' ${ }^{3}$ The ECT, whose purpose is to establish a legal framework to promote long-term cooperation in the energy

1 For an overview of known ECT investor-State disputes, see Energy Charter Secretariat, 'All Investment Dispute Settlement Cases' < https://energycharter.org/what-we-do/dispute-settle ment/all-investment-dispute-settlement-cases/> accessed 17 December 2018.

2 Thomas Wälde and Abba Kolo, 'Environmental Regulation, Investment Protection and "Regulatory Taking" in International Law' (2001) 50 ICLQ 811, 815-817.

3 Mark Fenwick and Stefan Wrbka, 'The Shifting Meaning of Legal Certainty' in Mark Fenwick and others (eds), Legal Certainty in a Contemporary Context: Private and Criminal Law Perspectives (Springer 2016) 1. See also Paul Craig, 'Formal and Substantive Conceptions of 
field, explicitly obliges Contracting Parties to create 'stable, equitable, favourable and transparent' conditions for investors while also calling on States to formulate 'stable and transparent legal frameworks.' ${ }^{4}$

This article argues that it is desirable for a certain level of predictability to exist in the interpretation and application of the treaty by adjudicators, congruent with the principles of the rule of law. ${ }^{5}$ However, this does not mean that absolute consistency should be pursued - law should be capable of evolving over time and absolutism might even go so far as to deliver unjust results. ${ }^{6}$ Especially for a treaty whose substantive investment standards incorporate terms as 'fair', 'equitable', and 'unreasonable', absolute consistency ought not be the aim. The content of these notions may evolve and the factual circumstances of each specific case are often of great importance. ${ }^{7}$ Indeed, it may even be desirable for case law to evolve in order to incorporate changing societal circumstances and demands. Therefore, the author does not argue in favour of binding precedents and the application of the principle of stare decisis in investment arbitration. Rather, he advances the thesis that when decisions taken diverge from previous decisions; these ought to contain reasons setting forth the relevant considerations while at the same time ensuring a certain level of predictability in ECT investor-State dispute settlement.

Like decisions rendered under other IIAs, various ECT provisions have been interpreted and applied inconsistently by arbitral tribunals and domestic

the Rule of Law: An Analytical Framework' in Richard Bellamy (ed), The Rule of Law and the Separation of Powers (Routledge 2005) 95.

4 Energy Charter Treaty (Annex I of the Final Act of the European Energy Charter Conference) (signed 17 December 1994, entered into force 16 April 1998) (1995) 34 ILM 373 (ECT) arts 2, 10(1). See also Concluding Document of The Hague Conference on the European Energy Charter (signed 17 December 1991) title I <https://energycharter.org/fileadmin/DocumentsMedia/ Legal/1991_European_Energy_Charter.pdf > accessed 28 November 2018.

5 Brian Z Tamanaha, On the Rule of Law: History, Politics, Theory (CUP 2004) 66, 97, 119; Stephan W Schill, 'The Sixth Path: Reforming Investment Law from Within' in Jean E Kalicki and Anna Joubin-Bret (eds), Reshaping the Investor-State Dispute Settlement System: Journeys for the $21 s t$ Century (Brill Nijhoff 2015) 621, 632; Colin M Brown, 'A Multilateral Mechanism for the Settlement of Investment Disputes. Some Preliminary Sketches' (2017) 32(3) ICSID Rev 673, 676-680; Stephan W Schill, 'Reforming Investor-State Dispute Settlement: A (Comparative and International) Constitutional Law Framework' (2017) 20(3) JIEL 649, 655-656.

6 Michael Ewing-Chow, 'Coherence, Convergence and Consistency in International Investment Law' in Roberto Echandi and Pierre Sauvé (eds), Prospects in International Investment Law and Policy: World Trade Forum (CUP 2013) 228, 231-233; Thomas Schultz, 'Against Consistency in Investment Arbitration' in Zachary Douglas, Joost Pauwelyn and Jorge E Viñuales (eds), The Foundations of International Investment Law: Bringing Theory into Practice (OUP 2014) 297 .

7 Concerning the evolution of the international minimum standard, see Rudolf Dolzer and Christoph Schreuer, Principles of International Investment Law (2nd edn, OUP 2012) 139-141. 
courts. Moreover, ECT tribunals sometimes explicitly criticise one another when examining comparable arguments. ${ }^{8}$ This issue arises in part due to the vague nature of various ECT provisions, which increases the likelihood of inconsistent interpretations. Another issue relates to the multiplicity of cases involving comparable matters, causing confusion when tribunals render contradictory awards in relation to the same challenged measure(s). ${ }^{9}$ Hence, after having reviewed the implementation of the investment chapter of the ECT, the Energy Charter Conference announced in 2017 that it would consider the need to modernise a treaty and, more recently, approved a list of topics for the discussion on the modernisation of the treaty. ${ }^{10}$ The next step in the modernisation process is to identify potential policy options for the relevant topics and analyse the instruments that can be used to implement any future decision." ${ }^{11}$ This article contributes to this discussion.

To that end, Section 2 outlines some of the inconsistencies in ECT case law. Section 3 subsequently examines the potential causes of these inconsistencies. In Section 4, available tools to address these inconsistencies are identified. As such, this part contains an analysis of those options currently being considered by the Energy Charter Conference, including amendments or additional protocols to legally binding instruments (e.g. to the treaty) as well as soft law alternatives such as interpretations by the Contracting Parties in the form of

The Blusun $v$ Italy tribunal, for example, criticised the standard of review proposed by the Charanne and Construction Investments $v$ Spain, SCC Case No V 062/2012, Award (21 January 2016) tribunal concerning a legitimate expectations claim regarding support for a renewable energy project, see Blusun SA, Jean-Pierre Lecorcier and Michael Stein v Italian Republic, ICSID Case No ARB/14/3, Final Award (27 December 2016) para 318. The Novenergia $v$ Spain tribunal openly disagreed with the standard of review of legitimate expectations as proposed by the Eiser Infrastructure Limited and Energía Solar Luxembourg Sàrlv Kingdom of Spain, ICSID Case No ARB/13/36, Final Award (4 May 2017) tribunal, see Novenergia II - Energy \& Environment (SCA) (Grand Duchy of Luxembourg), SICAR $v$ The Kingdom of Spain, SCC Arb No 063/2015, Final Award (15 February 2018) para 694 .

9 Spain, Italy, and the Czech Republic are all facing various claims as a result of regulatory changes to their renewable energy support schemes. Turkey was involved in several ECT cases brought by businessman Cem Cengiz Uzan while in all ECT cases involving the Russian Federation questions concerning the provisional application of the treaty arise.

10 Energy Charter Secretariat, Decision of the Energy Charter Conference on the Modernisation of the Energy Charter Treaty (28 November 2017) CCDEC 201723 STR, para 2. Energy Charter Secretariat, 'Approved Topics for the Modernisation of the Energy Charter Treaty' (29 November 2018) <https://energycharter.org/media/news/ article/approved-topics-for-the-modernisation-of-the-energy-charter-treaty/?tx_news _ pi1\%5Bcontroller\%5D=News\&tx_news_pi1\%5Baction\%5D=detail\&cHash=3da319e52a 7 8fa54058bc2co8eecc214> accessed 17 December 2018. 
an Energy Charter Declaration. ${ }^{12}$ Before concluding, the paper will also consider inter se modification of the ECT by a group of like-minded States, as well as strengthening the role of non-disputing ECT Contracting Parties in ongoing disputes.

First, several examples of inconsistent rulings in ECT investor-State cases are provided to illustrate the problem at hand.

\subsection{The Definition of 'Investment': Does a Contract Debt Qualify as Such?}

Adjudicators have taken different approaches to the question whether contract debts can qualify as a protected investment under the ECT in the absence of an 'underlying' investment, such as any fixed assets. As a tribunal's decision to hear a dispute is contingent on the threshold question of the existence of an 'investment', a consistent approach is desirable. ${ }^{13}$

In several ECT cases the investment at issue consisted of a claim to money where that claim did not arise out of an economic activity carried out by an underlying asset in the host State. In that regard, in Energoalliance v Moldova, the tribunal held that contract debts could qualify as an investment, thereby arguably following in the footsteps of Petrobart $v$ Kyrgyz Republic in which the term 'investment' was interpreted broadly. ${ }^{14}$ In his dissenting opinion, Dominic Pellew, the President of the Energoalliance tribunal, clarified that he disagrees with the finding that acquired contract debt could qualify as investment protected under the ECT because, amongst others, the acquisition of debt does not contribute to the economy of the host State. ${ }^{15}$ Initially, in 2016, Pellew's position was confirmed by the Paris Court of Appeals, which set aside the Energoalliance award on the basis of similar arguments. ${ }^{16}$ In March 2018, however, the Court of Cassation held the Appellate Court to have erred in

\footnotetext{
12 Energy Charter Secretariat, 'Modernisation Decision' (n 10) para 1.

13 ECT, art $1(6)$.

14 Energoalliance Ltd $v$ the Republic of Moldova, UNCITRAL, Unofficial Translation of the Arbitral Award (25 October 2013) paras 225-227. See also Petrobart Limited $v$ the Kyrgyz Republic, SCC Arb No 126/2003, Final Award (29 March 2005) 70-72; Republic of Kyrgyzstan $v$ Petrobart Limited, CA Svea, 19 January 2007, Case No T5208-05, 9.

15 Energoalliance Ltd $v$ the Republic of Moldova, UNCITRAL, Dissenting Opinion of Arbitrator Dominic Pellew (25 October 2013) paras 3, 26. Pellew, however, was outvoted by the party appointed arbitrators.

16 Republique de Moldavie v Société Komstroy, CA Paris, 1e Ch, 12 April 2016, nº 13/22531, 6.
} 
setting aside the award. ${ }^{17}$ Although the Court of Cassation did not explicitly state that Energoalliance's investment should qualify as such under the ECT, it considered the Court of Appeals to be wrong in holding a contribution to the host State economy to be a qualificatory requirement by virtue of the ECT. ${ }^{18}$

In the factually comparable Energorynok $v$ Moldova case, the tribunal rejected contract debt to amount to an investment under the ECT. ${ }^{19}$ One should note, however, that the award in Energorynok was rendered after Energoalliance but before the ruling of the Paris Court of Appeals. Notwithstanding, the mere fact that various courts and tribunals have come to different conclusions in comparable cases leads to uncertainty over the boundaries of the term 'investment'; a term that determines both the scope of the treaty and the jurisdiction of a tribunal. At the 2018 Energy Charter Conference, the definition of 'investment' was included in the list of approved topics for the modernisation discussions. ${ }^{20}$

\subsection{Application of the Standards of Investment Protection}

A second phenomenon is the inconsistent interpretation of the standards of investment protection in ECT investor-State dispute settlement. One example particular to the provisions of the ECT concerns the significance of the first sentence of Article 10(1) ECT, which provides that '[e]ach Contracting Party shall ... encourage and create stable, equitable, favourable and transparent conditions for investors of other Contracting Parties to make Investments in its Area.' At dispute is whether this sentence contains an autonomous standard that provides for a distinct cause of action or whether it is simply an introduction to the rest of Article 10(1) ECT, which outlines the various standards of investment protection, including the FET standard.

In its 2013 decision, the Energoalliance $v$ Moldova tribunal appeared to view the first sentence of Article 10(1) ECT as a distinct obligation, holding that the respondent had violated its obligation 'to create "stable, equitable, favourable and transparent conditions" for Claimant's investment' because

17 Energoalians SARL (Komstroy) v Republique de Moldavie v, Civ 1ère, 28 March 2018, $\mathrm{n}^{\circ}$ 16-16568, ECLI:FR:CCASS:2018:C100352.

18 The contribution to the development of the host State may be relevant when defining the term 'investment' under the ICSID Convention, see Christoph H Schreuer and others, The ICSID Convention: A Commentary (2nd edn CUP 2009) 129-134; Damien Charlotin, 'Energy Charter Treaty Award Is Revived by Court, Re-Stoking Debate as to Whether a "Contribution" Is an Essential Feature of an Investment- or Whether a Mere "Claim to Money" Also Qualifies' (IAReporter, 10 April 2018).

19 State Enterprise 'Energorynok' $v$ the Republic of Moldova, SCC Arb No V2012/175, Final Award (29 January 2015) para 101.

Energy Charter Secretariat, 'Approved Topics' (n 10). 
the investor had been denied justice. ${ }^{21}$ The AES $v$ Kazakhstan tribunal, on the other hand, held an entirely different view in a decision rendered a week after Energoalliance:

[T] he first sentence of Article 10(1) of the ECT ... is an introductory sentence aimed at putting the further obligations laid out in Article 10(1) of the ECT into perspective. As such, it has mainly programmatic character and does not provide for an independent standard of protection or right of action of a kind that is sufficiently specific to be relied upon by an investor. $^{22}$

In 2016, this uncertainty was further exacerbated. The Blusun $v$ Italy tribunal held that none of the sentences of Article 10(1) are 'merely hortatory or preambular' and that the significance of the first sentence extends beyond the 'initial making of the investment' while in Isolux $v$ Spain, on the basis of the conclusion reached in the Plama $v$ Bulgaria case, the tribunal rejected the argument that the first sentence contained an autonomous obligation altogether. ${ }^{23}$

During the modernisation process, various standards of investment protection will be discussed as reflected by the 2018 decision of the Energy Charter Conference, including the standards relating to FET, Most Favoured Nation (MFN) treatment, most constant protection and security, compensation for losses, indirect expropriation, and the observance of obligations. ${ }^{24}$

\subsection{The Relationship Between the ECT and European Union Law}

A third issue that has given rise to fundamentally different conclusions is the relationship between the ECT and European Union (EU) law. Resort to ECT-based dispute settlement has increased significantly in intra-EU relations since the privatisation and liberalisation of, and consequent increase in cross-border investment activity in, European energy markets. Fundamental questions relating to the intra-EU applicability of the ECT and its compatibility with EU law remain contentious. The relevance of this topic has increased exponentially since the ruling of the Court of Justice of the European Union

\footnotetext{
21 Energoalliance Ltd (n 14) para 356.

22 AES Corporation and Tau Power BV v the Republic of Kazakhstan, ICSID Case No ARB/ 10/16, Award (1 November 2013) para 380.

23 Blusun (n 8 ) paras 319, 342. See also Plama Consortium Limited v The Republic of Bulgaria, ICSID Case No ARB/03/24, Award (27 August 2008) para 173; Isolux Infrastructure Netherlands BVv The Kingdom of Spain, SCC Arb No V2013/153, Final Award (17 July 2016) paras 764-766.

24 Energy Charter Secretariat, 'Approved Topics' (n 10).
} 
(CJEU) in Achmea v Slovakia, in which the CJEU held arbitration clauses in intra-EU Bilateral Investment Treaties (BITs) to be incompatible with EU law. ${ }^{25}$

In the Electrabelv Hungary case, the tribunal held that EU law prevails over the ECT 'in case of any material inconsistency' while the opposite conclusion was reached in RREEF $v$ Spain. ${ }^{26}$ Furthermore, in AES $v$ Hungary, a case factually comparable to Electrabel, the tribunal took EU law into account as a 'fact' in the same manner as it did national law upon the urging of both parties. ${ }^{27}$ The tribunal added thereto that it was mindful 'that a State may not invoke its domestic law as an excuse for alleged breaches of its international obligations. ${ }^{28}$

Does the relationship between EU law and the ECT perhaps differ depending on the subject matter of the issue at hand? The Vattenfall tribunal held that the ECT cannot be interpreted in a manner 'so as to give priority to external treaties', such as the EU treaties, in relation to jurisdiction while it remained silent on any such relationship in case of an incompatibility between the ECT and EU law that relates to the merits. ${ }^{29}$ Furthermore, by reference to the lex specialis rule on conflict of laws, the tribunal resolved the friction between the conflict clauses of the ECT and the Treaty on the Functioning of the EU in favour of the ECT. ${ }^{30}$ It seems safe to say that, with regard to these two aspects, the Vattenfall tribunal thus considered the ECT to prevail over EU law.

The relationship between the ECT and EU law is not explicitly dealt with in the text of the ECT. ${ }^{31}$ During the ECT negotiations, however, the European Commission proposed to preclude the application of the ECT in intra-EU relations whenever relevant EU rules concerning the particular subject could be

25 CJEU, Case C-284/16, Slovak Republic v Achmea BV, ECLI:EU:C:2018:158.

26 Electrabel SA $v$ Republic of Hungary, ICSID Case No ARB/o7/19, Decision on Jurisdiction, Applicable Law and Liability (30 November 2012) para 4.191; RREEF Infrastructure (GP) Limited and RREEF Pan-European Infrastructure Two Lux Sàrlv Kingdom of Spain, ICSID Case No ARB/13/30, Decision on Jurisdiction (6 June 2016) para 87. AES Summit Generation Limited and AES-Tisza Erömü Kft v The Republic of Hungary, ICSID Case No ARB/07/22, Award (23 September 2010) para 7.6.6.

28 ibid.

29 Vattenfall $A B$ and Others $v$ Federal Republic of Germany, ICSID Case No ARB/12/12, Decision on the Achmea Issue (31 August 2018) paras 109, 131. Where it concerns an alleged lack of jurisdiction because of an inconsistency between the ECT and EU law, the Electrabel tribunal held that certain arguments based on EU law cannot be taken into account 'because they are based on a hierarchy of legal rules seen only from the perspective of an EU legal order applying within the EU, whereas this tribunal is required to operate in the international legal framework of the ECT and the ICSID Convention, outside the European Union.' See Electrabel (n 26) para 4.112.

$30 \quad$ Vattenfall (n 29) paras 222-229.

31 One may very well argue that Article 16 of the ECT applies to this relationship. 
relied upon. ${ }^{32}$ It is clear, given the current text of the treaty, that this proposal was rejected. ${ }^{33}$

As alluded to before, the Achmea judgment of the CJEU underlines the relevance of this topic. Although this ruling did not concern an ECT case, and one can thus argue the Achmea case to be irrelevant for intra-EU ECT cases, the CJEU is expected to rule on intra-EU ECT arbitration in Novenergia $v$ Spain. ${ }^{34}$ At present, the European Commission regularly intervenes in intra-EU disputes and argues that intra-EU ECT arbitration is incompatible with EU law. ${ }^{35}$ ECT tribunals have rejected these objections thus far. ${ }^{36}$ However, in light of Achmea, ECT tribunals might find it more difficult to maintain such a position and could be forced to address the systemic consequences of the incompatibility between the ECT and EU law. This might, in turn, give rise to seemingly inconsistent decisions wherein legal considerations beyond the ECT could come into play, such as whether the tribunal operates under the Convention on the Settlement of Investment Disputes between States and Nationals of Other States (ICSID Convention) that established the International Centre for Settlement of Investment Disputes (ICSID) or not and, if not, whether the tribunal is seated within or outside the EU. ECT tribunals seated in the EU legal order, and thus operating under the supervision of the CJEU, might be more

32 The disconnection clause, which was proposed for inclusion in what is now Article 24 ECT, stated '[i]n their mutual relations, Contracting Parties which are members of the EC shall apply Community rules and shall not therefore apply the rules arising from this Agreement except insofar as there is no Community rule governing the particular subject concerned.' See Letter from Secretary-General Clive Jones to Ambassador Rutten (19 February 1993); Draft Basic Agreement for the European Energy Charter (12 August 1992) 84 , comment 27.18 .

33 Vattenfall (n 29) paras 201-206.

34 Masdar Solar \& Wind Cooperatief UA $v$ The Kingdom of Spain, ICSID Case No ARB/14/o1, Award (16 May 2018) paras 678-683; Antin Infrastructure Services Luxembourg Sàrl and Antin Energia Termosolar BVv The Kingdom of Spain, ICSID Case No ARB/13/31, Award (15 June 2018) para 224;. Vattenfall (n 29) para 163. See also Damien Charlotin, 'Post-Achmea Developments: Spain Wants Court to Ask ECJ to Rule on Compatibility of Energy Charter Treaty with EU law; 'Achmea Ruling also Touted by Poland as Reason for Discontinued BIT Case' (IAReporter, 22 May 2018).

35 Electrabel (n 26) paras 4.1-4.199; Blusun (n 8) paras 277-303; Masdar (n 34) paras 296-342.

36 Charanne and Construction Investments $v$ The Kingdom of Spain, SCC Arb No o62/2012, Unofficial Translation of the Final Award (21 January 2016) paras 424-450; RREEF (n 26) paras 78-80; Blusun (n 8) para 303; Isolux (n 23) paras 622-60; Eiser Infrastructure Limited and Energía Solar Luxembourg Sàrlv The Kingdom of Spain, ICSID Case No ARB/13/36, Final Award (4 May 2017) paras 197-204; Novenergia (n 8) paras 449-466; Antin (n 34) paras 224-230; Masdar (n 34) paras 296-342. 
receptive to arguments based on the primacy of EU law than ICSID tribunals or those ECT tribunals seated outside the EU legal order. ${ }^{37}$

The aforementioned uncertainty regarding the relationship between the ECT and EU law is problematic for European investors and EU Member States alike. ${ }^{38}$ With approximately 60 percent of all known ECT disputes intra-EU in nature, many of which are still pending, Achmea has only exacerbated the uncertainty reigning to date. ${ }^{39}$ Although domestic courts can indeed settle ECT investor-State disputes, an avenue compatible with EU law, arbitration seems to be the preferred avenue. ${ }^{40}$ Whether intra-EU ECT arbitration is still (effectively) available remains to be seen.

\subsection{Provisional Application of the ECT}

A final example that clearly illustrates the practical consequences of inconsistencies is the set of contradictory rulings on Article 45 ECT concerning the provisional application of the treaty. While neither the Russian Federation nor Belarus has ratified the ECT, both apply the treaty provisionally on the basis of Article 45 ECT. ${ }^{41}$ However, Article 45 contains a rather ambiguous limitation clause which has given rise to divergent interpretations. ${ }^{42}$

This divergence can be illustrated by reference to the Yukos $v$ Russian Federation case, wherein the ECT tribunal and the District Court of the Hague rendered inconsistent decisions. In essence, the ECT tribunal accepted that Article 45 ECT allows for the provisional application of the ECT 'as a whole' pending entry into force, unless 'the principle of provisional application itself were inconsistent "with [the State's] constitution, laws, or regulations." ${ }^{43}$ This conclusion finds support in an earlier ECT deliberation, namely Kardassopoulosv Georgia, and has since also been adopted in two other ongoing arbitrations

37 Cees Verburg and Nikos Lavranos, 'Recent Awards in Spanish Renewable Energy Cases and the Potential Consequences of the Achmea Judgment for Intra-EU ECT Arbitrations' (2018) 3 European Investment Law and Arbitration Review 197, 214-5.

38 All EU Member States are a Contracting Party to the ECT although Italy withdrew in 2016. Italy is, however, bound to the sunset clause of the ECT.

39 Eric Leikin and Martina Magnarelli, "The Future of Intra-EU ECT Claims in the Face of EC Opposition: Boom or Bust?' (Kluwer Arbitration Blog, 15 September 2017) <http://arbitra tionblog.kluwerarbitration.com/2017/09/15/icca-2/> accessed 2 October 2018.

40 ECT, art 26(2)(a).

41 The Russian Federation withdrew from the treaty in 2009.

42 ECT, art 45 reads 'Each signatory agrees to apply this Treaty provisionally pending its entry into force for such signatory in accordance with Art. 44, to the extent that such provisional application is consistent with its constitution, laws or regulations.'

43 Yukos Universal Ltd v Russian Federation, PCA Case No AA227, UNCITRAL, Interim Award on Jurisdiction and Admissibility (30 November 2009) para 301. 
against the Russian Federation on the topic of the Yukos bankruptcy.4 The District Court of the Hague, however, saw things differently. It held that the 'option of provisional application is focused on and depends on the compatibility of separate treaty provisions with national laws', concluding that Russia was not bound by Article 26 ECT and that the ECT tribunal lacked jurisdiction. ${ }^{45}$ Under the approach of the District Court, one has to examine the compatibility of the treaty provision at issue with the constitution, laws, and regulations of a given State. This stands in stark contrast with the approach of ECT tribunals. The latter deem the ECT provisionally applicable as a whole unless the principle of provisional application as such is inconsistent with the constitution, laws, or regulations of a Contracting Party.

These examples, although by no means an exhaustive overview of all conflicting outcomes in ECT cases, clearly illustrate the presence of inconsistencies that are particular to the ECT. Nevertheless, despite the presence of inconsistencies, one must also point out that there are areas of convergence in ECT jurisprudence; such as the interpretation and application of the provisions on denial of benefits and indirect expropriation. ${ }^{46}$

44 Ioannis Kardassopoulos $v$ Georgia, ICSID Case No ARB/05/18, Decision on Jurisdiction (6 July 2007) paras 223, 246. See also Luke E Peterson, 'In Second-Wave Yukos Arbitration, McLachlan and Rowley See Russia as Provisionally Bound by Energy Charter Treaty' (IAReporter, 16 February 2017); Jarrod Hepburn, 'Interim Award in Luxtona v. Russia Arbitration Comes to Light, Offering New Reasoning on Provisional Application of Energy Charter Treaty and Russia's Attempted Denial of Benefits to this Yukos Shareholder' (IAReporter, 4 January 2018).

45 Russian Federation v Yukos Universal Ltd, Rb The Hague (20 April 2016), Case No C/og/ 477162 / HA ZA 15-2, para 5.18.

46 In relation to Article 17 of the ECT, tribunals have held that the right to deny benefits has to be actively exercised and can only have prospective - and not retrospective or retroactive - effects. See eg Plama Consortium Limited $v$ The Republic of Bulgaria, ICSID Case No ARB/03/24, Decision on Jurisdiction (8 February 2005) paras 155-162; Yukos (n 43) paras 456-459; Liman Caspian Oil BV and NCL Dutch Investment BVv The Republic of Kazakhstan, ICSID Case No ARB/07/14, Excerpts of the Award (22 June 2010) paras 224-226; Khan Resources Inc, Khan Resources BV, and Cauc Holding Company Ltd $v$ The Government of Mongolia, PCA Case No 2011-09, UNCITRAL, Decision on Jurisdiction (25 July 2012) paras 421-431; Masdar (n 34) paras 232-243. Concerning indirect expropriation claims, ECT tribunals have adopted the so-called 'sole effects doctrine', albeit with slightly different nuances. See eg Nykomb Synergetics Technology Holding AB $v$ The Republic of Latvia, SCC Arb No 118/2001, Award (16 December 2003) para 4.3.1; Plama (n 23) paras 191-193; Mohammad Ammar Al-Bahloul v The Republic of Tajikistan, SCC Arb No Vo64/2008, Partial Award on Jurisdiction and Liability (2 September 2009) paras 279-281; Liman Caspian Oil (n 46) para 293; AES (n 27) para 14.3.1; Electrabel (n 26) para 6.53-6.64; Mamidoil Jetoil Greek Petroleum Products Societe SA v The Republic of Albania, ICSID Case No ARB/11/24, Award (30 March 2015) paras 561-572; Charanne (n 36 ) paras 
Having established that irregularities exist, one can investigate the causes at heart of these inconsistencies.

\subsection{Ad Hoc Nature of Arbitration and Lack of Appeal Mechanism}

A first potential cause of the various inconsistencies is the ad hoc nature of arbitration, the primary mechanism to settle investor-State disputes, and the lack of an appeal mechanism. Arguably, arbitration is a suitable mechanism to settle disputes between the parties involved, but less capable of contributing to the development of the law by enunciating a consistent body of case law. In national and international legal systems where appeals mechanisms exist, the highest authority can ensure a consistent application of the law and simultaneously steer the development thereof. International investment law lacks such an appeals mechanism as recourse at the seat of arbitration or the annulment procedure under the ICSID Convention is merely possible on very limited grounds. ${ }^{47}$ Inconsistent arbitral decision-making is one of several reasons underlying the EU's move away from investor-State dispute settlement through arbitration towards a court-based system with an appeals mechanism, as evidenced by recent EU IIAs and ongoing efforts at UNCITRAL to establish a multilateral investment court. ${ }^{48}$

Since the applicable law in all ECT disputes is the same, namely the 'treaty and applicable rules and principles of international law', one might expect decisions to be somewhat consistent or at least evidence convergence - especially since investment tribunals, including ECT tribunals, have acknowledged the importance of consistency in and the relevance of earlier arbitral decisions. ${ }^{49}$ Nevertheless, this has only happened in a handful of areas with inconsistencies remaining in others.

Generally, divergence in arbitral decision-making is more seemingly prevalent in international investment law than in other areas of public international

460-461; Isolux (n 23) paras 835-839; Foresight Luxembourg Solar 1 SÁRL, Foresight Luxembourg Solar 2 SÁRL, Greentech Energy System A/S, GWM Renewable Energy I SPA and GWM Renewable Energy II SPA v Kingdom of Spain, SCC Arb No V 2015/150, Final Award (14 November 2018) para 429. Slightly less unequivocal support for the 'sole effects doctrine' can be found in Blusun (n 8) paras 398-400.

47 Jeswald W Salacuse, The Law of Investment Treaties (OUP 2015) 434.

48 Brown (n 5) 677.

49 ECT, art 26(6). See eg Saipem SpA v The People's Republic of Bangladesh, ICSID Case No ARB/05/07, Decision on Jurisdiction and Recommendation on Provisional Measures (21 March 2007) para 67; Mamidoil (n 46) para 565 . 
law that use arbitration to settle disputes. In the law of the sea, for example, along with two international adjudicatory bodies, arbitration has played a major role in maritime delimitation cases. ${ }^{50}$ Although this area of law indeed also has no appellate review, the interaction between various courts and tribunals has been described as 'mutually reinforcing.51 This might, in part, be due to significant overlap between the judges and arbitrators in the law of the sea cases - since tribunals are often comprised of former, current, or future judges from relevant international courts. ${ }^{52}$ In ECT arbitration, the group of arbitrators is much more diverse: out of the 144 individuals appointed in ECT cases, 80 arbitrators received just one appointment. ${ }^{53}$ Having such plurality in decision makers, noting in particular the unavoidable differences in terms of their background, might contribute to inconsistencies as each may hold different views or adopt different approaches to examine the relevant matters. ${ }^{54}$ This suggests that the modernisation process of the ECT ought to consider the possibility of a centralised appellate facility, a dedicated ECT court, or a roster of arbitrators for ECT disputes. However, these options are currently not being considered in the modernisation process. ${ }^{55}$

\subsection{Textual Deficiencies}

A second potential cause of incoherence is the text of the ECT itself which has been said 'not [to be] a paragon of drafting clarity' since it, like many other

5o Bernard H Oxman, 'Courts and Tribunals: The ICJ, ITLOS, and Arbitral Tribunals' in Donald R Rothwell and others (eds), The Oxford Handbook of the Law of the Sea (OUP 2015) 394 .

51 Barbara Kwiatkowska, 'The Eritrea-Yemen Arbitration: Landmark Progress in the Acquisition of Territorial Sovereignty and Equitable Maritime Boundary Delimitation' (2001) 32 Ocean Dev \& Intl L 1, 14-15; Chao Wang, 'International Arbitration of Maritime Delimitation: An Alternative for East Asia' (2014) $7 \mathrm{~J} \mathrm{E}$ Asia \& Intl L 427, 433.

$5^{2}$ J Ashley Roach, 'Arbitration under the Law of the Sea Convention' in John N Moore (ed), International Arbitration: Contemporary Issues and Innovations (Martinus Nijhoff 2013) 135, 140-143.

53 UNCTAD, 'Investment Policy Hub' < http://investmentpolicyhub.unctad.org/> accessed 28 November 2018. This figure includes individuals appointed in all known pending, concluded, and discontinued cases of which the relevant information is publicly available. Arbitrators that were initially appointed but subsequently replaced during the process have not been included.

54 Lars Markert, 'International Investment Law and Treaty Interpretation - Problems, Particularities and Possible Trends' in Rainer Hofmann and Christian J Tams (eds), International Investment Law and General International Law: From Clinical Isolation to Systemic Integration? (Nomos 2011) 53, 61-64; August Reinisch, 'The Interpretation of International Investment Agreements' in Marc Bungenberg and others (eds), International Investment Law: A Handbook (CH Beck 2015) 372, 407-408.

55 Energy Charter Secretariat, 'Approved Topics' (n 10). 
IIAs, lacks guidance on many important issues. ${ }^{56}$ The FET standard, the MFN obligation, the umbrella clause, and the prohibition on unreasonable measures that impair an investment are all open to divergent interpretations. ${ }^{57}$ More recent IIAs, such as the Comprehensive and Progressive Agreement for Trans-Pacific Partnership (CPTPP) and the Comprehensive Economic and Trade Agreement (CETA), usually contain more guidance in relation to some of these problematic standards. ${ }^{58}$

Another textual deficiency is the definition of 'investment' discussed above. According to Article 1(6) ECT, a claim to money or performance pursuant to a contract can constitute an 'investment' when it has 'economic value' and is 'associated with an Investment.' As noted by two ECT tribunals, the term 'investment' is thus in certain circumstances defined by reference to 'investment', making the definition circular and 'rais[ing] a logical problem [that] creates some doubt about the correct interpretation.59 Therefore, one can argue that the root of the inconsistency problem lies in the text of the ECT itself, simply because it lacks guidance on so many important issues.

Of course, one could likewise maintain that many IIAs were deliberately drafted vaguely in order to 'cover the broadest range of investment situations.' 60 While this may be true, at least from the perspective of the capital exporting countries, one can question whether the content of IIAs was properly negotiated by all parties. ${ }^{61}$ As stated by Professor Schreuer, acting as an expert in a case against Argentina, in response to the question whether 'he really believed that two sovereign States will negotiate, sign and ratify a Bilateral Investment Treaty without caring to consider what was put in it':

56 Mahnoush H Arsanjani and W Michael Reisman, 'Provisional Application of Treaties in International Law: The Energy Charter Treaty Awards' in Enzo Cannizzaro (ed), The Law of Treaties: Beyond the Vienna Convention (OUP 2011) 86, 91-93.

Mamidoil (n 46) para 599; Margie-Lys Jaime, 'Relying upon Parties' Interpretation in Treaty-Based Investor-State Dispute Settlement: Filling the Gaps in International Investment Agreements' (2014) 46 Geo J Intl L 261, 272-281; Tarcisio Gazzini, Interpretation of International Investment Treaties (Hart 2016) 91-100.

$5^{8}$ cf the FET standard contained in art 10(1) ECT with Comprehensive and Progressive Agreement for Trans-Pacific Partnership (adopted 8 March 2018, not entered into force) (CPTPP) art 9.6; Comprehensive Economic and Trade Agreement (European Union-Canada) (adopted 30 October 2016, not entered into force) (CETA) art 8.10.

59 Petrobart (n 14) 72; Energorynok (n 19) paras 83-84.

6o Luke E Peterson, Bilateral Investment Treaties and Development Policy-Making (IISD 2004) 27 .

61 For a critical account of the investment treaty making process, see Lauge N Skovgaard Poulsen, Bounded Rationality and Economic Diplomacy: The Politics of Investment Treaties in Developing Countries (CUP 2015). 
... in the majority of times, BITs are among clauses of treaties that are not properly negotiated. BITs are very often pulled out of a drawer, often on the basis of some sort of a model, and are put forward on the occasion of state visits when the heads of states need something to sign, and the typical two candidates in a situation like that are Bilateral Investment Treaties, and treaties for cultural co-operation. ${ }^{62}$

Note, in this regard, that the first draft of the investment chapter of the ECT was also based on a model treaty: the 1991 Model BIT of the United Kingdom, which itself was drafted just months before what would eventually become the ECT. ${ }^{63}$ Also, the negotiating history of Article 1o ECT, which contains the vast majority of the standards of treatment, reveals that these standards were barely discussed. Rather, nearly all debate concerning Article 10 focused on the inclusion of pre-establishment rights. ${ }^{64}$

That being the case, one can question whether the negotiators of the ECT were aware of the potential implications of the unqualified standards of treatment in IIAs, given that the first arbitration award based on an IIA was only rendered in 1990, and, more significantly, the first cases involving unqualified FET standards were not decided until 2000. ${ }^{65}$

62 Wintershall Aktiengesellschaft v Argentine Republic, ICSID Case No ARB/04/14, Award (8 December 2008) para 85.

63 cf Draft Treaty of the Basic Protocol to the European Energy Charter (20 August 1991) arts 18-23 with 1991 UK Model BIT, arts 2-7. The UK Model BIT was likely taken as inspiration simply because a member of the British delegation was the chairman of the working group where the ECT was being negotiated and, hence, it were the British that initiated the compilation of a full first draft of the treaty. See Letter from Martin Rickerd to Jonathan Cook (23 August 1991), which accompanied the first draft and read, 'I enclose a copy of the first full draft of the Basic Protocol. I think you will agree that Andrew Young, our Legal Adviser, has done an excellent job in pulling together the contributions from around Whitehall into a (remarkably concise) homogenous text.' See also Letter from Secretary-General Clive Jones to European Commissioner Cardoso E Cunha ( 5 September 1991), which likewise stated, "The major work during August has been the preparation by the UK of a draft Basic Protocol, in their role as Chairman of Working Group II. In the course of this work they have been supported by the NL Presidency and Conference Secretariat.'

64 The author has done research at the archives of the Energy Charter Secretariat.

65 Asian Agricultural Products Ltd $v$ The Republic of Sri Lanka, ICSID Case No ARB/87/3, Final Award (27 June 1990); Metalclad Corporation v The United Mexican States, ICSID Case No ARB(AF)/97/1, Award (30 August 2000); Emilio Agustín Maffeziniv The Kingdom of Spain, ICSID Case No ARB/97/7, Award (13 November 2000). See also Dolzer and Schreuer (n 7 ) 130. 
At present it seems that providing clarity to ambiguous ECT provisions is one of the core elements of the modernisation process. ${ }^{66}$

\subsection{Adversarial Nature of Investment Arbitration}

Thirdly, the fact that arbitration - the primary mechanism for ECT investorState dispute settlement - is an adversarial rather than inquisitorial process may also influence the outcome of a case. ${ }^{67}$ Arbitrators may decide a case based on the arguments and evidence presented to them, meaning that the conduct of the counsellors representing the disputing parties can have a significant and direct - impact on the outcome of the case.

Khan $v$ Mongolia illustrates this matter. In this case, the investor invoked provisions of the Mongolian Foreign Investment Law through the umbrella clause of the ECT, arguing that the obligation to 'observe any obligations entered into' included the observation of domestic statutory obligations. ${ }^{68}$ The tribunal held that, as Mongolia had not put forward a different interpretation of the provision, it would accept the claimant's interpretive argument. ${ }^{69}$ Had counsel for Mongolia argued, on the basis of previous ECT awards and the text of the treaty itself, that domestic statutory provisions had to be 'entered into' by Mongolia with the investor - thus limiting the scope of the provision to consensual obligations only - the case might have been decided differently. ${ }^{70}$ The fact that Mongolia's counsel did not do so would eventually trigger Mongolia's liability for a breach of the umbrella clause. ${ }^{71}$

Similarly, the Khan case might have been decided differently had the tribunal applied the principle of jura novit curia - on the basis of which ECT tribunals are seen to know the law and may apply it on their own initiative. ${ }^{72}$ Despite the fact that the International Court of Justice accepts this principle,

66 Energy Charter Secretariat, 'Approved Topics' (n 10).

67 Jan H Dalhuisen, Dalhuisen on Transnational Comparative, Commercial, Financial and Trade Law, vol 1 (Hart Publishing 2016) 422-426, 605-607, 649-650.

68 See, in particular, the last sentence of art 10(1) ECT. See also Khan (n 46) para 438.

69 ibid.

$70 \quad$ Plama (n 23) para 186; Mohammad Ammar Al-Bahloul (n 46) para 257; Liman Caspian Oil (n 46) para 448; Isolux (n 23) paras 767-771.

71 Khan Resources Inc, Khan Resources BV, and Cauc Holding Company Ltd $v$ The Government of Mongolia, PCA Case No 2011-09, UNCITRAL, Award on the Merits (2 March 2015) paras $295^{-296,366 . ~}$

72 Hans van Houtte and Maurizio Brunetti, 'Investment Arbitration - Ten Areas of Caution for Commercial Arbitrators' (2013) 29 Arb Intl 553, 571; Eric De Brabandere, Investment Treaty Arbitration as Public International Law (CUP 2014) 101. 
its application in investment arbitration, especially in non-ICSID procedures, remains more contested..$^{73}$

As investment arbitration intrinsically involves public interests, it has been argued that it is desirable for arbitrators to adopt a more inquisitorial attitude than would be required from their counterparts in commercial arbitration. ${ }^{74}$

\subsection{Arbitrator Remuneration}

Fourthly, the remuneration scheme for the arbitrators' fees may influence one's incentive to write an elaborately reasoned award which, in turn, may enhance the overall quality of the award and, consequently, contribute to the consistency of ECT awards more generally. ${ }^{75}$ Even though the present author does not wish to question the integrity and motives of arbitrators, the importance of legal reasoning cannot be overstated since a fully reasoned award is, among others, likely to reveal the analytical process adopted by the tribunal which may benefit parties' acceptance of the outcome. ${ }^{76}$ Although it is admittedly difficult to support this argument with evidence, the strongly varying quality and persuasiveness of ECT awards is remarkable. ${ }^{77}$

Article 26 ECT permits four different sets of arbitration rules with diverging fee structures: under the ICSID Convention and the ICSID Additional Facility Rules, the arbitrators' fee is USD 3,000 per day; the UNCITRAL rules dictate that ' $[t]$ he fees and expenses of the arbitrators shall be reasonable in amount, taking into account the amount in dispute, the complexity of the subject matter, the time spent by the arbitrators and any other relevant circumstances of

73 Fisheries Jurisdiction (United Kingdom of Great Britain and Northern Ireland v Iceland) (Merits) [1974] ICJ Rep 3, para 17; Compañiá de Aguas del Aconquija SA and Vivendi Universal SA v Argentine Republic, ICSID Case No ARB/97/3, Decision on Annulment (3 July 2002) para 84; CME Czech Republic BVv The Czech Republic, UNCITRAL, Final Award (14 March 2003) para 411; Mr Patrick Mitchell $v$ The Democratic Republic of the Congo, ICSID Case No ARB/99/7, Decision on the Application for Annulment of the Award (1 November 2006) para 57; RSM Production Corporation v Grenada, ICSID Case No ARB/05/14, Decision on RSM Production Corporation's Application for a Preliminary Ruling (7 December 2009) para 23; Marco Gavazzi and Stefano Gavazziv Romania, ICSID Case No ARB/12/25, Award of the Tribunal (18 April 2017) paras 210-212. See also De Brabandere (n 72) 101-110.

74 Stephan W Schill, 'Crafting the International Economic Order: The Public Function of Investment Treaty Arbitration and Its Significance for the Role of the Arbitrator' (2010) 23 LJIL 401, 422-423; De Brabandere (n 72) 115-116.

75 Schill (n 74) 424-428; Dalhuisen (n 67) 619-627.

76 Hersch Lauterpacht, The Development of International Law by the International Court (Grotius 1982) 37-45.

77 Schill has developed a comparable argument but focused on the quality of the reasoning of arbitral awards rendered under various institutional rules, see Schill (n 74) 424-428. 
the case'; whereas the Stockholm Chamber of Commerce (SCC) rules state that arbitrator fees are determined by the amount in dispute. ${ }^{78}$

Some prime examples of ECT awards that do not provide for elaborate legal reasoning happen to be SCC awards, suggesting that this approach to the calculation of fees may incentivise arbitrators to provide only brief reasons for their decisions when the amount in dispute is relatively low. The tribunals in Nykomb v Latvia and Petrobartv Kyrgyz Republic were both very concise in their analysis and primarily applied the facts of the case to the ECT without providing clear legal reasoning as to the meaning of said ECT provisions. ${ }^{79}$ About the Petrobart award, Zukova even went so far as to state that 'the failure of the tribunal to provide adequate reasoning for its determinations calls the credibility and authority of the final award into question. ${ }^{\prime} 0$

This phenomenon can perhaps best be contrasted with the Yukos cases, where the tribunal operated under the UNCITRAL arbitration rules and the arbitrators were not bound to a flat fee remuneration scheme. In stark contrast to the aforementioned SCC cases, the arbitrators in the Yukos cases received between EUR 1,5 and 2 million respectively with even the tribunal's assistant taking home almost EUR 1 million. ${ }^{81}$ The reasoning in the Yukos awards is however substantially more extensive and elaborate, with the Interim and Final Awards amounting to nearly $85^{\circ}$ pages combined.

\subsection{Lack of Participation ECT Contracting Parties in the Interpretation of the Treaty}

Finally, the very limited role that ECT Contracting Parties have played in the interpretation process of the ECT after the conclusion of the treaty may have precluded them from filling in the blanks of those ambiguous ECT provisions.

78 UNCITRAL Arbitration Rules (1976) 15 ILM 701, art 39(1). UNCITRAL Arbitration Rules (as revised in 2010) art 41(1); Arbitration Rules of the Arbitration Institute of the Stockholm Chamber of Commerce (entered into force 1 January 2017) (SCC Arbitration Rules) appendix IV, sch costs art 2.

79 For example, in Nykomb, the tribunal's analysis of expropriation and discrimination was limited to one paragraph respectively. Fees in this case were limited to EUR 90,00o for the chairman and EUR 49,500 for the party appointed arbitrators. See Nykomb (n 46) paras 4.3.1, 4.3.2, 7. Likewise, in Petrobart, the legal reasoning with respect to ECT provisions is very limited. The chairman in this case received EUR 55,066 and the party appointed arbitrators EUR 33,040. See Petrobart (n 14) 88-89.

8o Galina Zukova, 'The Award in Petrobart Limited v Kyrgyz Republic' in Guillermo Alvarez and Michael Reisman (eds), The Reasons Requirement in International Investment Arbitration: Critical Case Studies (Brill 2008) 323, 347.

81 Yukos Universal Limited $v$ The Russian Federation, PCA Case No AA 227, Final Award (18 July 2014) paras 1860-1863. 
Of course, those States that have found themselves in the role of respondent have contributed to the interpretation of the ECT. Aside those, the participation of other Contracting Parties is rather limited. To date, the European Commission serves as the only example of a Contracting Party intervening as amicus curiae in cases wherein it is not the respondent.

Under NAFTA, by comparison, all of the Contracting Parties have actively participated in the interpretation of the NAFTA, other than acting as respondent, in two ways. Firstly, in 2001, acting through the NAFTA Free Trade Commission, parties adopted a binding interpretive note on Article 1105 NAFTA, which contains the FET standard. ${ }^{82}$ The Free Trade Commission did so on the basis of Article 1131(2) NAFTA. ${ }^{83}$ These agreements between the Contracting Parties on the interpretation of the treaty may also be relevant even if the applicable treaty does not contain an explicit provision similar to NAFTA, although such agreements may than not be binding upon a tribunal. For example, Article 31(3)(a) of the Vienna Convention on the Law of Treaties (VCLT) states that '[a]ny subsequent agreement between the parties regarding the interpretation of the treaty or the application of its provisions' shall be taken into account when interpreting the treaty. ${ }^{84}$ Various NAFTA tribunals identified both Article 1131 NAFTA and Article 31(3)(a) VCLT as a legal basis to take the interpretive note into account. ${ }^{85}$ The ECT contains no such mechanism, although a declaration to that effect is possible. The International Law Commission has confirmed that, to that end, unanimous agreement by all parties to the treaty 'constitutes a true interpretative agreement which represents the will of the "masters of the treaty" and thus an authentic interpretation.'86

$82 \quad$ NAFTA Free Trade Commission, 'North American Free Trade Agreement Notes of Interpretation of Certain Chapter 11 Provisions' (31 July 2001) (NAFTA Notes of Interpretation) <www.sice.oas.org/tpd/nafta/commission/chwunderstanding_e.asp> accessed 28 November 2018.

83 North American Free Trade Agreement (United States-Canada-Mexico) (adopted 17 December 1992, entered into force 1 January 1994) (1993) 32 ILM 289 (NAFTA) art 1131(2).

84 Vienna Convention on the Law of Treaties (adopted 23 May 1969, entered into force 27 January 1980) 1155 UNTS 331 (VCLT) art 31(3)(a).

85 Methanex Corporationv United States of America, UNCITRAL, Final Award of the Tribunal on Jurisdiction and the Merits (3 August 2005) pt II ch B paras 11-21; The Canadian Cattlemen for Fair Trade $v$ United States of America, UNCITRAL, Award on Jurisdiction (28 January 2008) paras 181-184; William Ralph Clayton, William Richard Clayton, Douglas Clayton, Daniel Clayton and Bilcon of Delaware Inc v Government of Canada, PCA Case No 2009-04, UNCITRAL, Award on Jurisdiction and Liability (17 March 2015) para 430.

86 International Law Commission, 'Report of the International Law Commission on the Work of Its 63rd Session' (26 April-3 June and 4 July-12 August 2011) UN Doc A/66/10/ Add.1, 559. 
NAFTA practice demonstrates that such action by the treaty parties can have a significant influence on tribunal decision-making. ${ }^{87}$

Secondly, non-disputing State Parties of NAFTA have intervened in ongoing arbitration proceedings by virtue of Article 1128 NAFTA, which allows a NAFTA Party to 'make submissions to a Tribunal on a question of interpretation of this Agreement.' This provision 'provides an official channel through which the parties can agree upon such interpretation, without taking position on the facts related to the dispute before the Tribunal. ${ }^{88}$ Such submissions may constitute either a 'subsequent agreement' under Article 31(3)(a) VCLT or 'subsequent practice' under Article 31(3)(b) VCLT, which shall be taken into account by a tribunal when interpreting the treaty. ${ }^{89} \mathrm{~A}$ review of NAFTA practice shows that non-disputing States tend to submit restrictive interpretations, which, if endorsed by all treaty parties, are often taken into account by tribunals - although not so unequivocally as when binding interpretations are issued. ${ }^{90}$

The adoption of such formal mechanisms to facilitate the Contracting Parties' involvement in treaty interpretation would be well worth consideration by the Energy Charter Conference during its modernisation process. Unfortunately, it currently is not on the list of approved topics. ${ }^{91}$

\section{Enhancing Legal Certainty in ECT Dispute Settlement}

While it is impossible to discuss the remedies against all causes of inconsistencies in ECT dispute settlement in the confines of one article, this section explores some of the options available through which to enhance legal certainty in ECT procedures. The identification of available tools to implement

87 Andrea J Menaker, 'Treatment of Non-Disputing State Party Views in Investor-State Arbitrations' in Arthur W Rovine (ed), Contemporary Issues in International Arbitration and Mediation: The Fordham Papers 2008, vol 2 (Brill 2009) 59, 67.

88 Gazzini (n 57) 193.

89 Canadian Cattlemen (n 85) paras 186-189; Meg N Kinnear, Andrea K Bjorklund and John FG Hannaford, Investment Disputes Under NAFTA: An Annotated Guide to NAFTA Chapter 11 (Kluwer Law International, 2006-2009) 1128-4C; Gazzini (n 57) 193.

9o Menaker (n 87) 68-73; Gabrielle Kaufmann-Kohler, 'Non-Disputing State Submissions in Investment Arbitration: Resurgence of Diplomatic Protection?' in Laurence Boisson de Chazournes, Marcelo Kohen and Jorge E Viñuales (eds), Diplomatic and Judicial Means of Dispute Settlement (Brill 2012) 307, 314; Wolfgang Alschner, "The Return of the Home State and the Rise of "Embedded" Investor-State Arbitration' in Shaheeza Lalani and Rodrigo Polanco Lazo (eds), The Role of the State in Investor-State Arbitration (Brill 2015) 293, 311.

91 Energy Charter Secretariat, 'Approved Topics' (n 10). 
any decision on the modernisation of the ECT is also explicitly on the agenda for the Subgroup on Modernization in $2019 .{ }^{92}$

\subsection{Amending the ECT}

The most obvious manner in which to address shortcomings in the text of the ECT would be by amending problematic provisions. This could be a viable long-term solution that allows parties to clarify the content of treaty provisions and/or facilitate the establishment of a central ECT appellate mechanism.

However, in the short run, this is unlikely to yield effective results. Amending the ECT might be difficult since Article 36(1)(a) ECT requires unanimity of those parties present - and voting - at the Energy Charter Conference. Also, even if amendments are adopted, these will only affect the relations between Contracting Parties that have ratified said amendments. ${ }^{93}$ The ECTs Trade Amendment, concluded in 1998 and entered into force in 2010, is an example of a successful amendment to the treaty. However, the fact that it took twelve years for the amendment to come into force also highlights the slow pace of the procedure. Combined with the knowledge that the Trade Amendment is limited in its ambition; its main purpose was to update the ECTs trade regime with the rules and practices under the World Trade Organization (WTO) Agreements, a speedy textual modernisation does not bode well.

\subsection{Energy Charter Protocol}

A second possible solution could be to conclude an Energy Charter Protocol, defined in Article 1(13)(a) ECT as:

a treaty, the negotiation of which is authorized and the text of which is adopted by the Charter Conference, which is entered into by two or more Contracting Parties in order to complement, supplement, extend or amplify the provisions of this Treaty with respect to any specific sector or category of activity within the scope of this Treaty, or to areas of co-operation pursuant to Title III of the Charter.

An unsuccessful instance wherein the ECT parties tried to negotiate an additional protocol is the Transit Protocol. ${ }^{94}$ Taking heed of that attempt, an

92 ibid.

93 ECT, art 42.

94 Lothar Ehring and Yulia Selivanova, 'Energy Transit' in Yulia Selivanova (ed), Regulation of Energy in International Trade Law: WTO, NAFTA and Energy Charter (Kluwer 2011) 49, 95-104; Katja Yafimava, 'Transit: The EU Energy Acquis and the Energy Charter Treaty' in 
important question that is at the core of any ECT protocol that is to be adopted in the future, which addresses investment protection or dispute settlement, relates to the effect of Article 16 ECT. In essence, Article 16 ECT allows investors to rely on those provisions most favourable to them in cases where ECT Contracting Parties have adopted an international agreement dealing with investment protection or dispute settlement. Practically, this means that if the ECT parties adopt a protocol that, for example, provides for a lower level of investment protection or introduces less favourable dispute settlement procedures, investors would be able to circumvent these new rules by reference to Article 16. Of course, the ECT Contracting Parties can always remove Article 16 from the treaty altogether through an amendment.

Another issue concerning a possible Energy Charter Protocol is the fact that it would be consent-based and, as such, would only apply to those ECT parties that voluntarily submit thereto, meaning it does 'not derogate from the rights and obligations of those Contracting Parties not party to the Protocol.'95 This implies that the contemporary provisions of the ECT would remain in force vis-à-vis those ECT parties that do not consent to the new protocol, a situation of identical practical outcome to that of an ECT amendment that has not been ratified by all ECT parties. Consequently, situations may arise in which diverging rights and obligations exist amongst the ECT constituency.

\subsection{Inter se Modification of the Treaty}

Given the difficulties associated with amending the ECT or concluding a subsequent protocol, especially in light of Article 16 ECT, a prospective manner in which to align the ECT with contemporary policy preferences between like-minded States would be by inter se modification on the basis of Article 41 VCLT. ${ }^{96}$ According to Fitzmaurice and Merkouris, inter se modification is an 'essential technique, and a necessary safety valve, for the adjustment of

Kim Talus (ed), Research Handbook on International Energy Law (Edward Elgar 2014) 593, 611-623.

95 ECT, art 33(5).

96 On the basis of VCLT, art 41 ' $[\mathrm{t}$ ] wo or more of the parties to a multilateral treaty may conclude an agreement to modify the treaty as between themselves' if there is no prohibition in the treaty, the modification does not affect the rights and obligations of other parties to the treaty and it 'does not relate to a provision, derogation of which is incompatible with the effective execution of the object and purpose of the treaty as a whole.' These conditions are cumulative, see Anne Rigaux and Denys Simon, 'Article 41 Agreements to Modify Multilateral Treaties Between Certain of the Parties Only' in Olivier Corten and Pierre Klein (eds), The Vienna Conventions on the Law of Treaties: A Commentary (OUP 2011) $986,1002$. 
treaties to the dynamic needs of international society.97 Mindful of the controversy surrounding the content of investment treaties, such a modification procedure could be used as a 'safety valve'. ${ }^{8}$ Since the ECT does not contain a prohibition on modification and one could argue that the obligations concerning investment promotion and protection under the ECT are reciprocal rather than absolute, certain ECT parties would be able to modify ECT obligations between themselves without affecting those rights of ECT parties uninvolved in the process. ${ }^{99}$

Although inter se modification would not be ideal for the same reasons enumerated in Section 4.2, it would allow a group of like-minded States to adjust the investment chapter to their needs. Upon reaching critical mass within the Energy Charter Conference, one could aim for more structural, long-term reforms. For example, since the ECT is currently primarily invoked in intra-EU relations, the EU and its Member States could modify the ECT inter se, thereby leaving the rights of non-EU investors within the EU unaffected by the modification. In particular, the EU and its Member States may use this tool to address the concerns the CJEU espoused in the Achmea judgment by removing the reference to arbitration in Article 26 and merely provide for intra-EU ECT dispute settlement through the domestic courts of the host State, placing any dispute firmly within the EU legal order under the guiding supervision of the CJEU. ${ }^{100}$ Of course, any proposed modification would have to meet the three criteria of Article 41(1) VCLT. ${ }^{101}$ This implies that certain aspects of the ECT cannot be modified inter se. For example, if the EU and its Member States would like to modify the rules regarding transit, by excluding

97 Malgosia Fitzmaurice and Panos Merkouris, 'Re-Shaping Treaties While Balancing Interests of Stability and Change: Critical Issues in the Amendment/Modification/ Revision of Treaties' (2018) 20 Austrian Review of International and European Law 41, 44.

98 ibid 44-5.

99 Rigaux and Simon (n 96) 1003-1005.

100 See Verburg and Lavranos (n 37).

101 In Vattenfall, the European Commission argued that provisions of the EU Treaties in effect modified certain provisions of the ECT between EU Member States through Article 41 VCLT. The tribunal rejected this argument since the provisions relied upon were provisions of the EU Treaties, ie different international agreements instead of an agreement relating to the modification of the ECT itself. In passing, the tribunal mentioned that Article 16 is a prohibition on modification. According to the present author, this is however a misconstruction of the text of Article 16 ECT which regulates the relationship between the ECT and other international agreements that concern investment protection and dispute settlement. It does not, however, say anything about the inability to modify the text of the ECT itself. See Vattenfall (n 29) paras 220-221. 
the intra-EU applicability thereof, this would affect the rights and obligations of neighbouring countries contrary to Article 41(1)(b)(i) VCLT.

\subsection{Energy Charter Declaration}

A fourth solution, much less time consuming and politically difficult, may be to clarify the content of the treaty rules in their current form.

The ECT provides for the adoption of an Energy Charter Declaration, which is defined in Article 1(13)(b) ECT as a 'non-binding instrument, the negotiation of which is authorized and the text of which is approved by the Charter Conference, which is entered into by two or more Contracting Parties to complement or supplement the provisions of this Treaty' A declaration by the Contracting Parties may constitute an authoritative subsequent agreement regarding the interpretation of ECT provisions in the sense of Article 31(3)(a) VCLT or may be considered as 'subsequent practice in the application of the treaty' under Article 31(3)(b) VCLT and, through the application of the rules of treaty interpretation, influence ECT dispute settlement. Thus, although the ECT does not contain a procedure to adopt interpretations that are binding upon tribunals akin NAFTA, ECT Contracting Parties may resort to this soft law instrument. ${ }^{102}$ Nevertheless, to increase the chances that such declarations will have the desired effect, two matters need to be kept in mind.

First, to enhance the authority of the declaration its adoption should be unanimous. ${ }^{103}$ Unanimity is preferred over consensus since, in the case of unanimity, all parties have explicitly agreed to the declaration while, in the case of consensus, the agreement is implicit because of the absence of objections. Second, the declaration should clarify the content of the existing rules of the treaty as opposed to attempting to amend it; the latter approach would undermine the authority of the declaration. ${ }^{104}$ Two examples thereof are illustrated below.

An attempt of the ECT Contracting Parties to tie the FET standard of the ECT to the international minimum standard of treatment under customary

\footnotetext{
102 NAFTA, art 1131(2).

103 UN Doc A/66/10/Add.1 (n 86).

104 A similar point was made by the WTO Appellate Body in relation to the authority of WTO members to adopt interpretations of the WTO Agreements under Article IX:2 of the WTO Agreement, see WTO, European Communities: Regime for the Importation, Sale and Distribution of Bananas - Second Recourse to Article 21.5 DSU by Ecuador, Report of the Appellate Body (26 November 2008) WT/DS27/AB/RW2/ECU, para 383; WTO, European Communities: Regime for the Importation, Sale and Distribution of Bananas - Recourse to Article 21.5 of the DSU by the United States, Report of the Appellate Body (26 November 2008) WT/DS27/AB/RW/USA, para 383. See also Isabelle van Damme, 'Treaty Interpretation by the WTO Appellate Body' (2010) 21 EJIL 605, 612.
} 
international law, as happened under NAFTA, would probably be considered an amendment in disguise. ${ }^{105} \mathrm{~A}$ reference to the Liman Caspian Oil $v$ Kazakhstan case, where the tribunal held that the ECT's FET standard 'is to provide a protection which goes beyond the minimum standard of treatment under international law', illustrates this clearly. ${ }^{106}$ In light of that statement, the gist of which was recently repeated in Antin $v$ Spain, any claim by the ECT Contracting Parties that the FET standard of the ECT is supposed to provide the international minimum standard of treatment - and not the broader autonomous standard of treatment - is unpersuasive. ${ }^{107}$ Since States play a double role as, on the one hand, masters of the treaty and, on the other, potential or actual respondents in investment arbitration, tribunals may view interpretations perceived to be disguised amendments with scepticism. ${ }^{108}$

An example that may be more successful relates to the content of interpretive annexes commonly attached to modern IIAs dealing with indirect expropriation. ${ }^{109}$ These annexes aim to provide more clarity on where to draw the line between legitimate government regulation and indirect expropriation. ${ }^{110}$ In Philip Morris v Uruguay, based on the Uruguay-Switzerland BIT that contains an expropriation provision comparable to Article 13 ECT, the tribunal explicitly referred to such interpretive annexes despite that the applicable treaty did not contain such an annex. ${ }^{111}$ The fact that neither Switzerland nor Uruguay were involved in the treaties that the tribunal referred to was

105 See NAFTA Notes of Interpretation (n 82).

106 Liman Caspian Oil ( $\mathrm{n} 46)$ para 263.

107 Antin (n 34) para 530.

108 Christoph Schreuer, 'Diversity and Harmonization of Treaty Interpretation in Investment Arbitration' in Malgosia Fitzmaurice, Olufemi Elias, and Panos Merkouris (eds), Treaty Interpretation and the Vienna Convention on the Law of Treaties: 30 Years on (Martinus Nijhoff 2010) 129, 147-148; Anthea Roberts, 'Power and Persuasion in Investment Treaty Interpretation: The Dual Role of States' (2010) 104 AJIL 179, 179-180, 212-214; Michael Waibel, 'International Investment Law and Treaty Interpretation - Problems, Particularities and Possible Trends' in Hofmann and Tams (n 54) 29, 47-48; Jaime (n 57) 292; Reinisch (n 54) 405-407. See also Pope \& Talbot Inc $v$ The Government of Canada, UNCITRAL, Award in Respect of Damages (31 May 2002) para 47.

109 CETA, annex 8-A.

110 Philip Morris Brands Sàrl, Philip Morris Products SA and Abal Hermanos SA v The Oriental Republic of Uruguay, ICSID Case No ARB/10/7, Award (8 July 2016) para 300; Anne K Hoffmann, 'Indirect Expropriation' in August Reinisch (ed), Standards of Investment Protection (OUP 2008) 151, 166-167. The expropriation provision of CETA, art 8.12, mirrors ECT art 13 .

111 Philip Morris (n 110). See also Agreement Between the Swiss Confederation and the Oriental Republic of Uruguay on the Reciprocal Promotion and Protection of Investments (Switzerland-Uruguay) (adopted 7 October 1988, entered into force 22 April 1991) art 5(1). 
irrelevant as the tribunal was of the opinion that the annexes reflected the position under general international law. ${ }^{112}$ This suggests that a declaration reflective of the content of these annexes is more likely to be accepted by tribunals as an elucidation of the concept of indirect expropriation, rather than constituting an apparent amendment.

Thus, declarations of the Energy Charter Conference that contain more guidance on the content of ECT provisions can enhance legal certainty in ECT dispute settlement provided that they are adopted by unanimity and do not attempt to amend the treaty.

\subsection{Non-Disputing ECT Parties as Amicus Curiae}

Another method through which to increase the consistent interpretation of the ECT would be to strengthen the role of non-disputing ECT parties in ongoing arbitration cases and give them a more prominent role in the treaty interpretation process. The involvement of third parties can have a material effect on the outcome of proceedings. ${ }^{113}$ In the context of investment arbitration, the 2014 UNCITRAL Transparency Rules allow for submissions by a non-disputing party to the treaty. ${ }^{114}$ As stated above, non-disputing parties in NAFTA cases have a right to submit their views on the interpretation of the treaty. ${ }^{115}$ Similar provisions can be found in the Dominican Republic - Central America - United States Free Trade Agreement, the CPTPP, and the Canadian

112 Philip Morris (n 110) para 301.

113 See Understanding on Rules and Procedures Governing the Settlement of Disputes (Annex 2 of the Marrakesh Agreement Establishing the World Trade Organization) (adopted 15 April 1994, entered into force 1 January 1995) 1869 UNTS 401, arts 10, 17; Statute of the Court of Justice of the European Union [2012] OJ C83/210, art 23; Consolidated Version of the Rules of Procedure of the Court of Justice of 25 September 2012 [2012] OJ L265, art 96. See also Marc L Busch and Eric Reinhardt, 'Three's a Crowd: Third Parties and WTO Dispute Settlement' (2006) 58(3) World Politics 446, 447; Clifford Carrubba, Matthew Gabel and Charles Hankla, 'Judicial Behavior Under Political Constraints: Evidence from the European Court of Justice' (2008) 102 Am Pol Sci Rev 435, 449-450; Eugenia Levine, 'Amicus Curiae in International Investment Arbitration:The Implications of an Increase in Third-Party Participation (2011) 29 Berkeley J Intl L 200, 217; Katia Fach Gómez, 'Rethinking the Role of Amicus Curiae in International Investment Arbitration: How to Draw the Line Favorably for the Public Interest' (2012) 35 Fordham Intl LJ 510, 545.

114 UNCITRAL Rules on Transparency in Treaty-Based Investor-State Arbitration (effective from 1 April 2014) (UNCITRAL Rules on Transparency) art 5; Claudia Reith, 'The New UNCITRAL Rules on Transparency 2014: Significant Breakthrough or a Regime Full of Empty Formula?' in Marianne Roth and Michael Geistlinger (eds), Yearbook on International Arbitration, vol 4 (Intersentia 2015) 121, 136-137.

115 Kinnear, Bjorklund and Hannaford (n 89) 1128-1. 
and US Model BIT's. ${ }^{116}$ Likewise, the EU's trade and investment agreements with Canada, Singapore and Vietnam contain comparable provisions. ${ }^{117}$ The common denominator is that each limits the right of non-disputing parties to make submissions on issues regarding the interpretation of the agreement only.

\subsubsection{Applicable Arbitration Rules}

The absence of a specific ECT provision entitling non-disputing Contracting Parties to make submissions regarding the interpretation of the treaty can be considered a shortcoming. Nevertheless, the applicable arbitration rules may offer a solution and fill the gap left by the ECT.

Moreover, examples in ECT practice evidence that where non-disputing parties have made submissions to a tribunal, tribunals possess the discretion whether or not to admit such submissions and, in doing so, may impose conditions on their scope and levy costs on non-disputing parties.

For example, in AES v Hungary and Electrabel v Hungary, the European Commission participated in the proceedings as amicus curiae. ${ }^{118}$ These tribunals, both operating under the ICSID arbitration rules, allowed the Commission to intervene on the basis of Rule 37(2) of the ICSID arbitration rules. ${ }^{119}$ In the Electrabel case, the tribunal laid down parameters for the scope of the submission, although the permitted scope of the Commission's submissions went beyond mere issues regarding the interpretation of the ECT. ${ }^{120}$ In RREEF $v$ Spain, however, the ICSID tribunal twice rejected the Commissions' attempts to intervene. ${ }^{121}$ In Eiserv Spain, the ICSID tribunal allowed the Commission to make a submission contingent on its willingness to pay 'the additional costs of legal presentation reasonably incurred by the parties in responding to' the

1162012 US Model BIT, art 28; 2004 Canada Model BIT, art 35; CPTTP, art 9.23; Dominican Republic - Central America - United States Free Trade Agreement (adopted 5 August 2004, entered into force 1 January 2009) art 10.20.

117 CETA, art 8.38; EU-Singapore Investment Protection Agreement (European UnionSingapore) (adoption and entrance into force pending) art 3.17; EU-Vietnam Free Trade Agreement (European Union-Vietnam) (adoption and entrance into force pending) ch 8 , art 25 .

118 Electrabel, ICSID Case No ARB/o7/19, Procedural Order No 4 (28 April 2009); AES (n 27) paras 3.18-3.22; Electrabel SA v Republic of Hungary, ICSID Case No ARB/07/19, Award (25 November 2015) para 234.

119 Schreuer and others (n 18) 704.

120 Electrabel, Procedural Order No 4 (n 118) paras 24-26.

121 RREEF (n 26) paras 16-32. 
submission. ${ }^{122}$ In the latter instance, the submission was withdrawn because the Commission was unwilling to entertain such costs. ${ }^{123}$

In the Charanne $v$ Spain case, where the tribunal operated under the 2010 SCC rules, the European Commission was granted the opportunity to make amicus curiae submissions although it was neither given access to the case files nor allowed to attend the hearings. ${ }^{124}$ The 2017 SCC arbitration rules contain a right, subject to certain conditions, for non-disputing treaty parties to make submissions 'on issues of treaty interpretation' in a separate appendix for investment treaty disputes. ${ }^{125}$ This is an innovation when compared to the 2010 SCC arbitration rules. Notwithstanding, no ECT case has yet been decided under the new rules in which the issue of an amicus curiae submission arose.

Likewise, the 2013 UNCITRAL arbitration rules provide for submissions by non-disputing parties to the treaty 'on issues of treaty interpretation.'126 Whenever older versions of the UNCITRAL rules apply, the general procedural powers of UNCITRAL tribunals permit tribunals to accept submissions from non-disputing parties. ${ }^{127}$ Allowing third-party submissions falls in line with the practice of the Iran-United States Claims Tribunal, which operates under 1976 UNCITRAL arbitration rules and where 'outside involvement has been deemed acceptable.'128 Thus, even in investment arbitration based on the 1976 or 2010 UNCITRAL arbitration rules, there is room for non-disputing ECT Contracting Parties to make submissions to the tribunal regarding the proper interpretation of the treaty.

Nevertheless, an explicit endorsement by the Energy Charter Conference of this possibility is desirable. The NAFTA Contracting Parties for example, acting through the NAFTA Free Trade Commission, explicitly acknowledged by means of a statement that non-disputing parties, including parties other than the non-disputing NAFTA parties, may act as amicus curiae. ${ }^{129}$ This statement also sets certain criteria that have to be met by amicus curiae

\footnotetext{
122 Eiser ( $\left.\mathrm{n}_{3} 6\right)$ para 65.

123 ibid paras 66-70.

124 Charanne (n 36) paras 16, 49-6o.

125 See SCC Arbitration Rules, art 4, appendix III.

1262013 UNCITRAL Arbitration Rules, art 1(4); UNCITRAL Rules on Transparency, art 5.

127 UNCITRAL Arbitration Rules (1976), art 15(1); UNCITRAL Arbitration Rules (2013), art 17(1). See also David D Caron and Lee M Caplan, The UNCITRAL Arbitration Rules: A Commentary (OUP 2013) 30-31, 39-41; Clyde Croft, Christopher Kee and Jeff Waincymer, A Guide to the UNCITRAL Arbitration Rules (CUP 2013) 176, 192-193.

128 Caron and Caplan (n 127) 40. See also United States v Iran, Case No A17, Decision No Dec 37-A17-FT (18 June 1985) 8 Iran-US Cl Trib Rep 189, 191.

129 Statement of the Free Trade Commission on Non-Disputing Party Participation <www .sice.oas.org/TPD/NAFTA/Commission/Nondispute_e.pdf> accessed 6 March 2017.
} 
submissions. Subsequent NAFTA tribunals have explicitly referred to the Free Trade Commission's statement in determining whether to accept amicus submissions. ${ }^{130}$

Thus, investment tribunals who derive their jurisdiction from the ECT can allow non-disputing ECT parties to make submissions in ongoing cases - a possibility explicitly acknowledged in the 2017 SCC and 2013 UNCITRAL arbitration rules. The ICSID arbitration rules, so too, afford a certain amount of discretion to the tribunal. Under the 1976 and 2010 UNCITRAL rules, the general procedural powers of the tribunal will have to be exercised. A declaration by the Energy Charter Conference that reflects the content of Appendix III of the 2017 SCC arbitration rules would strengthen the position of non-disputing ECT Parties in this regard. Developments outside the context of the ECT could also strengthen the role of non-disputing third treaty parties. For example, if more ECT Contracting Parties would sign and ratify the 2014 Mauritius Convention on Transparency this could make the UNCITRAL Transparency Rules applicable in ECT disputes.

\subsubsection{Transparency}

It almost goes without saying that encouraging non-disputing ECT parties to participate in ECT arbitration requires enhanced transparency by way of disclosure of, primarily, the existence of disputes and, secondarily, relevant documents such as the notice of arbitration, the parties' submissions, and decisions rendered by tribunals. A State needs to be aware of a dispute in order to be able to participate. Currently, neither investors nor ECT States are obliged to inform the Energy Charter Secretariat of existing investor-State disputes. In order to make meaningful third-party submissions, non-disputing parties should be able to access the notification of intent to arbitrate, the notice of arbitration or, preferably, the memoranda of the disputing parties. ${ }^{131}$ In that context, the Energy Charter Secretariat could oversee the distribution of documents and other relevant information, comparable to the role of the WTO

130 Glamis Gold, Ltd v United States of America, UNCITRAL, Decision on Application and Submission by Quechan Indian Nation (16 September 2005) paras 9-13; Apotex Inc v The Government of the United States of America, UNCITRAL, Procedural Order No 2 on the Participation of a Non-Disputing Party (11 October 2011) paras 15-35; Eli Lilly and Company $v$ The Government of Canada, ICSID Case No UNCT/14/2, UNCITRAL, Procedural Order No 4 (23 February 2016) paras A-B.

131 In Glamis Gold, the non-disputing parties stated 'that it would be difficult to submit meaningful submissions without first examining the Parties' memorial and counter-memorial.' See Glamis Gold Ltd $v$ United States of America, UNCITRAL, Procedural Order No 6 (15 October 2005) para 11. 
Secretariat. Alternatively, if more ECT Contracting Parties ratify the Mauritius Convention, 'the Secretary-General of the United Nations or an institution named by UNCITRAL' shall act as repository. ${ }^{132}$ Either way, transparency is currently included on the approved list of topics for the ECTs modernisation. ${ }^{133}$

\section{Conclusion}

As happened in investor-State disputes under other IIAs as well, the case law of ECT disputes suffers from considerable inconsistencies. Considering the interests at stake in these procedures, a lack of legal certainty adversely affects all parties involved and undermines the ECT's goal of creating a legal framework that facilitates trade and investment in the energy sector.

While there are various potential causes of these inconsistencies, it is difficult to pinpoint one specific source noting the plurality of variables at the core of legal decisions. Moreover, the fact that investment cases are immensely factspecific means that one has to exercise due caution when comparing different cases with one another. Nevertheless, given the fact that the ECT's investment chapter prescribes the 'rule of law' in investor-State relationships, or so is often held, the very concept of the rule of law should be one the strongest arguments in favour of more consistency and predictability in ECT dispute settlement. If the purpose of the ECT is to establish a legal framework which promotes longterm cooperation in the energy sector, the treaty should at the very least be predictable for those subjected to it.

The ECT can be modernised through a variety of avenues. The Energy Charter Conference, acting in unanimity, can employ soft law tools to provide more clarity on the content of ECT provisions. This exercise might yield shortterm results. A group of like-minded States can agree on inter se modifications of the treaty, which, in turn, can provide the impetus for treaty reform. As a long-term solution, more far-reaching tools, such as amending relevant treaty provisions, may be necessary. Regardless of the approach that the parties use, the recently initiated modernisation process gives the ECT parties an excellent opportunity to explore these ideas and bring the treaty in line with 21st century policy views.

132 UNCITRAL Rules on Transparency, art 8.

133 Energy Charter Secretariat, 'Approved Topics' (n 10). 